\title{
The Effects Between Numerical Tabulations And Graphs Of Financial Information On The Judgment Of Investors
}

\author{
Shaio Yan Huang, National Chung Cheng University, Taiwan \\ Yu-Hsuan Chung, National Chengchi University, Taiwan \\ Wen-Wei Cheng, Deloitte \& Touche, Taiwan
}

\begin{abstract}
Due to developments in information markets and advancements in information technology, and with the rapidity of information flow on the Internet, it is vital to increase the level of information transparency. Disclosure methods of financial information have presently become an important topic of discussion. By using numerical tables, non-distorted graphs or distorted graphs of financial information, this research discusses whether financial information display types indeed influence investors' judgments and decisions. We investigate and analyze the use of graph disclosure in Taiwan and use experiment design methods to test the effect of investors' judgment by comparing different display types of financial information. Our results find graphs are used to display comparative than numerical financial information, showing how this can influence investors' awareness and judgments and use of graphs can be used to manipulate impressions (impression management).
\end{abstract}

Keywords: Financial Graphs, Impression Management, Graphic Distortions

\section{INTRODUCTION}

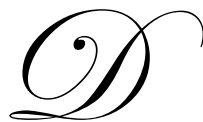

ue to rapid developments in information technology and the internet, people can easily learn about the situations of both enterprises and investors by looking at their websites. Horton (1993) indicates that within the diverse and international investment environment, using graphics can shorten the distance between languages and cultures. Many academics also believe that the use of graphics can facilitate the flow of account information (Holmes, 1984; Cunningham, 1990; Hussey, 1990). Hence, the use of graphics is a key characteristic of communication to a certain degree, and one that companies can effectively utilize in order to effectively make relevant financial information and management available.

Prior research has discovered that countries such as the United States of America, Australia, France, and the United Kingdom, among others, use financial graphics within their annual reports (Steinbart, 1989; Beattie and Jones, 1992b; Mather et al., 1996; Frownfelter and Fulkerson, 1998). Although many companies in Taiwan often use graphics to display pertinent financial information in order to communicate concisely with investors, Taiwan stipulates that graphics are not to be used in annual financial statements as a mode of expression. Therefore, this research will investigate and analyze the use of graph disclosure in Taiwan, and then test how the different display types of financial information, including numerical tables, non-distorted graphs or distorted graphs, affect investors' judgment.

Different from the use of numerals expression in financial reports, Leivian (1980) indicates that companies that use graphics in financial reports are more likely to attract the attention of readers, as well as increase their level of memory retention. Normally, visual graphics are a better form of displaying information than using numerical information. Beattie and Jones (2002) suggest that the use of graphics is an excellent tool for communicating 
financial information due to the visual effects of graphics, allowing the viewer to directly and immediately understand the content of the information. Additionally, the use of graphics as a mode of demonstrating financial information can also facilitate the speed of the viewer's ability to observe any discrepancies or other significant phenomena (Vessey, 1991). However, financial graphics do not really have clear guidance for information disclosure; even though the use of graphs has many benefits, the use of graphs will not necessarily change an investors' impression of a company with poor performance records.

Murphy and Zimmerman (1993) find that there are a number of factors motivating managers to provide financial information reports and financial disclosures, including demonstrating management and operational achievements. Also, the existence of the freedom to choose the measure, disclosure and expression of the financial statement allows managers to easily manipulate information in such a manner to create a positive impression.

Epstein and Pava (1993), Anderson and Epstein (1996), and Bartlett and Chandler (1997) demonstrate that non-expert investors in the market do not completely and carefully read financial reports, but have the tendency to scan the reports to get the gist of the content matter and the accounting statements. In light of this, investors' decisions and judgments rely on and refer to the use of graphics in financial reports. Meyer (1997) found that graphics are often used to help judgments and decisions, the use of which often convince the reader. Arunachalam and Steinbart (2002) present evidence that judgments can be influenced by the design of the graphics, discovering that inappropriate graphic design may cause the reader to make decisions he would not otherwise make. Moreover, Beattie and Jones (1992b) indicate that in a scenario where the graphics and ratio scales are inappropriate, the graphics may distort the information and influence the reader's cognizance. Consequently, investor decisions are contingent upon whether or not financial graphics are appropriately and clearly displayed.

The next section reviews the literature for financial information disclosure and graph distortion. We also analyze the use of graph disclosure in Taiwan to develop our hypotheses. Section 3 explains the research design and methodology. Section 4 presents the results, and we summarize our findings in Section 5.

\section{LITERATURE REVEIEW}

\section{Financial Information Disclosure Use of Financial Graphics}

In today's complicated and highly competitive economic environment, in order to globalize management, ensure immediate financial information communication, and retain proof of foreign capital investment and issue global deposit receipts (GDR), companies often need to provide financial reports that comply with other countries' stipulations of self-disclosed financial information, including graphics. It is hoped that through this method, global financial communication can be maintained. Research conducted by Horton (1993) indicates that within the diverse and global investment environment, graphics are used to shorten the distance between cultures and languages. Therefore, apart from financial reports normally seen, enterprises often separately announce new information, release public manuals, or disclose financial graphics online.

Different financial reports use numerals as a form of expression. Leivian (1980) showed that enterprises use graphics in their financial reports to communicate information that will easily attract the attention of the reader and facilitate the reader's memory retention. Normally, this helps in the communication of accounting information (Holmes, 1984; Cunningham, 1990; Hussey, 1990). In addition, Beattie and Jones (2002) believe that there are four main benefits to using graphics: (1)graphics use elaborate colors that stimulate the visual senses and increase attention; (2)graphics can give a direct and instantaneous sense of the information; (3)information can be quickly located and gathered; (4)information can be demonstrated and expressed vividly. Hence, using graphs not only expresses financial information in a more attractive way than the traditional use of numerals in financial reports, but it also minimizes the time required by the reader to analyze pertinent information and aid memory retention. This fact has encouraged companies to rely more heavily on the use of graphics as a means of effectively communicating 
information and conveying results and achievements.

In addition, because of different requirements and demands of expression, many different styles and categories of graphics have emerged. Gillian et al. (1998) raised the issue that the style of graphics chosen to display numerical information depends largely upon the nature of the reader and information. Courtis (1997) and Beattie and Jones (1999) separate and investigate these varying categories of graphics into four groups: column, bar, line and pie. They discovered in their analysis that column was used the most and exceeded 50\%. Frownfelter and Fulkerson (1998) came up with the six categories of bar/column, line, pie, stacked bar/column, area, and line-plus-bar. Their investigation found that many companies tend to prefer the use of bar/column as a medium for graphics.

Many displaying financial variables had also investigated in prior studies. (Steinbart, 1989; Beattie and Jones, 1992, 1999, 2000; Courtis, 1997; Mather et al., 2000; Frownfelter and Fulkerson, 1998). Steinbart's (1989) investigation found that of the entire 500 top American companies listed in the Fortune 500 magazine in 1986, graphics were used primarily to show financial variables (sales, net profit, dividends) in 319 companies; net profit was the most common variable which was displayed using graphics. The results of Beattie and Jones' (2000) investigation discovered that the annual reports of the top 50 companies between 1992 and 1993 in six countries Australia, France, Germany, Holland, the United Kingdom and the United States - used graphics as the principle means of displaying financial variables (cash flow, share dividends, share profit, profit, sales and return of equality (ROE)), with profit being displayed in graphics more than any others. In short, it is clear that graphics used to report financial variables are not necessarily uniform across the board, meaning that there is no consistent format of the use of graphics by companies in different countries.

Our research is based on the period of late 2004, investigating the graphs of financial information on the websites of 1143 companies listed on the TAIEX (Taiwan Exchange Market). This investigation discovered that disclosure graphics were found on the websites of around 15\% of listed and approximately $11 \%$ of OTC (Over the Counter) companies (please refer to table 2-1). The rubber industry used graphs the most at $40 \%$, and the software industry was next at $30.77 \%$. In addition, non-traditional manufacture industries, including electronic appliances, finance and insurance, electrical engineering and electronic industries, commonly used graphics to disclose information.

We also discovered that companies listed on the TAIEX mainly used the categories of bar, pie, bar cube chart, and run chart (please refer to table 2-2). Bar was used 26.5\% of the time and pie, $19.4 \%$. Moreover, our investigation ascertained that with regards to listed companies' disclosure graphics, each company's website had an average of 2.79 graphs.

Finally, we investigated the variables displayed in graphs, such as sales (business) income, ratio of schooling distribution, pre-tax or after-tax net profit, ratio of market category to sales, and pre-tax or after-tax EPS (please refer to table 2-3). We found that $37.43 \%$ of listed companies used graphics to disclose financial information. The variable 'sales revenue' was displayed with the highest frequency $(21.86 \%)$ on the websites of listed companies. 
Table 2-1 Graphic Disclosure of TAIEX Company Websites in Taiwan

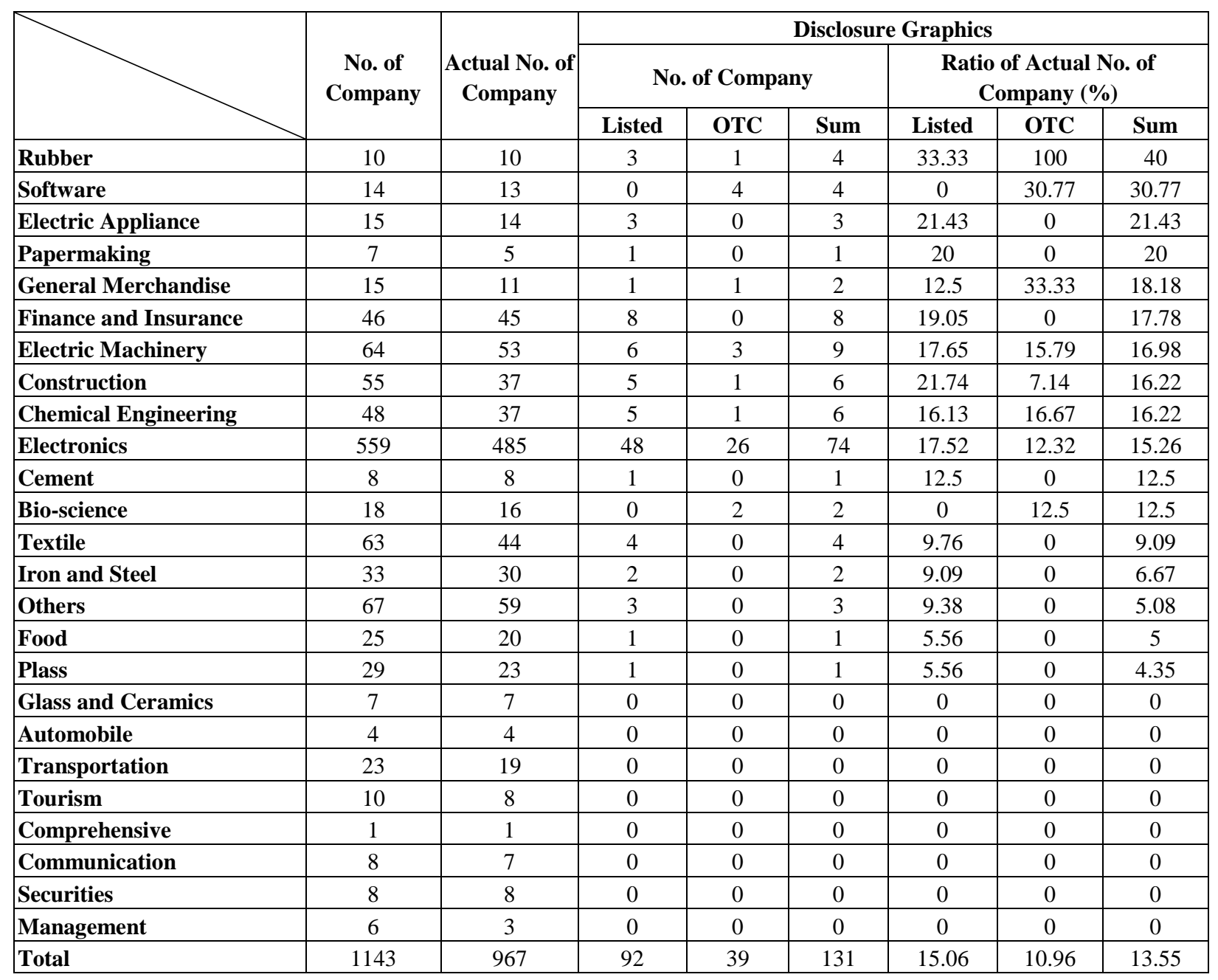

\section{Impression Management}

Paivio(1974) indicated that people have the ability to remember visual patterns. Using graphs is usually more effective than the written word or numerical tables. Tufte (1983) believes that using graphs can facilitate the effectiveness of a reader's memory. If a company displays information more than 3 items, it will be easier to comprehend a tendency of outcomes; contrarily, it is impossible to see a tendency as clearly, using accounting or numerical tables to display information. In addition, prior research has also indicated that using graphs is also more advantageous than using numerical tables when information is complicated (Blocher, Moffie and Zmud, 1986; DeSanctis and Jarvenpaa, 1989). Courtis (1997) shows that readers normally embrace, assimilate, and retain information faster and easier when graphs are used than tabulated numerals or written words. Carswell (1991) advanced this by purporting that the design of graphs can produce impression management, or the manipulation of the impression of a reader through the use of graphics. Meyer (1997) discovered that graphs are often used to convince and facilitate the formulation of decisions of readers.

This research considers that the use of graphs to display financial information facilitates impression management, and is visually more affective than numerical tables; thus, thereare different levels of effect and 
influence over the judgments of investors. This is established as Hypothesis 1.

H1: Using numerical tabulation of financial information has a different effect on the judgment of investors than using non-distorted graphs of financial information.

Table2-2 Graphs Display Type of TAIEX Company Websites in Taiwan

\begin{tabular}{|l|c|c|c|c|c|c|}
\hline \multirow{2}{*}{$\begin{array}{c}\text { Type of } \\
\text { Graphics }\end{array}$} & \multicolumn{2}{|c|}{ Listed Company } & \multicolumn{2}{c|}{ OTC Company } & \multicolumn{2}{c|}{ Listed \& OTC Company } \\
\cline { 2 - 7 } & No. of Use & $\begin{array}{c}\text { Ratio } \\
(\boldsymbol{\%})\end{array}$ & No. of Use & $\begin{array}{c}\text { Ratio } \\
(\%)\end{array}$ & No. of Use & $\begin{array}{c}\text { Ratio } \\
(\%)\end{array}$ \\
\hline Bar Chart & 66 & 22.68 & 31 & 41.33 & 97 & 26.50 \\
\hline Pie Chart & 66 & 22.68 & 5 & 6.67 & 71 & 19.40 \\
\hline Bar Cube Chart & 42 & 14.43 & 14 & 18.67 & 56 & 15.30 \\
\hline Line Chart & 23 & 7.90 & 2 & 2.67 & 25 & 6.83 \\
\hline Area Chart & 23 & 7.90 & 0 & 0 & 23 & 6.28 \\
\hline Line Chart + Bar Chart & 17 & 5.84 & 3 & 4.00 & 20 & 5.46 \\
\hline Column Chart & 9 & 3.09 & 9 & 12.00 & 18 & 4.92 \\
\hline Stacked Bar Chart & 8 & 2.75 & 8 & 10.67 & 16 & 4.37 \\
\hline H-Bar Chart & 12 & 4.12 & 0 & 0 & 12 & 3.28 \\
\hline Stacked Bar Cube Chart & 2 & 0.69 & 2 & 2.67 & 4 & 1.09 \\
\hline Line Chart + Bar Cube Chart & 1 & 0.34 & 1 & 1.33 & 2 & 0.46 \\
\hline Others & 22 & 7.58 & 0 & 0 & 22 & 6.01 \\
\hline Total & 291 & 100 & 75 & 100 & 366 & 100 \\
\hline
\end{tabular}

Table2-3 Use of Variable Graphs of TAIEX Listed and Websites in Taiwan

\begin{tabular}{|l|c|c|c|c|c|c|}
\hline \multicolumn{1}{|c|}{ Listed/OTC Company } & \multicolumn{2}{|c|}{$\begin{array}{c}\text { No. of Disclosure } \\
\text { Graphs for Listed } \\
\text { Company is 291 }\end{array}$} & \multicolumn{2}{|c|}{$\begin{array}{c}\text { No. of Disclosure } \\
\text { Graphs for OTC } \\
\text { Company is 75 }\end{array}$} & $\begin{array}{c}\text { No. of Disclosure } \\
\text { Graphs for Listed + } \\
\text { OTC Company is 366 }\end{array}$ \\
\cline { 2 - 8 } Graphic Variable & No. & Ratio (\%) & No. & Ratio (\%) & No. & Ratio (\%) \\
\hline $\begin{array}{l}\text { Sales (Business) Income (including Year, Quarter, } \\
\text { Month) }\end{array}$ & 64 & 22.00 & 16 & 21.33 & 80 & 21.86 \\
\hline Ratio of Schooling Distribution & 16 & 5.50 & 0 & 0 & 16 & 4.37 \\
\hline $\begin{array}{l}\text { Pre-tax or After-tax Net Profit (including Year, } \\
\text { Quarter, Month) }\end{array}$ & 11 & 3.78 & 3 & 4.00 & 14 & 3.83 \\
\hline Ratio of Market Category to Sales & 11 & 3.78 & 3 & 4.00 & 14 & 3.83 \\
\hline $\begin{array}{l}\text { Pre-tax or After-tax EPS } \\
\text { (including Year, Quarter, Month) }\end{array}$ & 10 & 3.44 & 3 & 4.00 & 13 & 3.55 \\
\hline Total & 112 & 38.49 & 25 & 33.33 & 137 & 37.43 \\
\hline
\end{tabular}

\section{Graphic Distortions}

The superior medium of displayed communication is a fundamental feature of graphs, which causes the reader to quickly assimilate and gather the content of the information transmitted so that he or she can easily 
understand, communicate and observe relationships and situations (Anderson, 1983; CICA, 1993; Jarett, 1993), however, it is also easy for graphs to be misleading, or ineffectual in communicating or transmitting information even more, for errors to exist (CICA, 1993). In addition, graphs are able to produce 'impression management,' easily creating distortions by the manipulation of information, or the careless mistakes, which can influence a reader's judgment. Moreover, graphs have a variety of styles, having different visual effects - and there is no authority which sets accurate graphic standards. Therefore, graph makers and management can easily take the opportunity to distort information or create graphic distortion errors.

Tufte (1983) has introduced six graphic design principles: (1)the depiction of the graph should be directly proportional to any changes in the numerical values; (2)graphs should be clearly labeled so as to prevent misunderstandings, and the amount of space used shall be limited; (3)any alterations to graphic design should be able to reflect changes to the numerical changes; (4)visual effects should not influence or distract the reader, causing him to pay particular attention to one aspect; (5)when depicting time series information, standardization of currency weightings often are superior to weightings of varying currencies; (6) providing the serial information pattern must provide at least 3 information points and depict accurate information pertinent to the situation. Furthermore, the United Kingdom Accounting Standards Board (ASB, 2000) produced recommendations related to graphs used in annual reports in regards to the selectivity of graphic displays, length of time series, distortion of measurements and simple two level spaces and so forth, and stated that more attention should be placed on the use of graphs.

Arunachalam and Steinbart (2002) collected information related to commonly inappropriate graphic designs, and separated them into four main categories: (1) Exaggerating the Magnitude of a Trend (by scaling the vertical axis improperly, not starting at the origin, or indicating a discontinuity in the scale), with inappropriate vertical representations in measurement criteria, such as not starting from the point of origin or non-continuous measurements. (2)'Masking' graphs (using only one vertical scale to include two variables that differ greatly in magnitude on the same graph) - such a type of graph that may disperse the reader's attention, easily resulting in erroneous judgments. (3)Reverse annual sequences-most languages are read from left to right; therefore most people expect to read a graph of time-series data from left to right (Gillian et al., 1998). When reversing the sequence of years, mistakes in understanding the information due to carelessness by the reader are common (misunderstanding annual profit increases, for instance). (4)Omitting and negative value, such as concealing information that shows the company in a bad light; if the reader doesn't review in any great detail, then certain information may be overlooked.

Prior research has shown the use and impact of inappropriate graphs used in company annual reports (Johnson et al, 1980, Steinbart, 1989, Beattie and Jones, 1992 and 1999, Courtis, 1997.) Steinbart's (1989) investigation of the biggest American companies taken from Fortune 500 in 1986 found that $26 \%$ of 319 companies had inappropriate graphs. This was the lowest figure. Courtis (1997) conducted a report on 327 Hong Kong company reports between 1994 and 1995 and found that over 52\% used inappropriate graphs.

Our research investigates the inappropriate graphs shown on the websites of the companies listed on the TAIEX. We found that 94 of a total of 366 graph disclosures were inappropriately formulated and designed, and $25.68 \%$ of graphs displayed on the websites of Taiwanese listed companies and OTC companies had undergone distortion, the most common type of which was 'Masking' at $14.21 \%$. The next most common distortion was not starting at the origin, with a discrepancy of $5.46 \%$ (please refer to table 2-4). 
Table 2-4 Situation of Inappropriate Graphs Used in TAIEX Company Websites in Taiwan

\begin{tabular}{|l|c|c|c|c|c|c|}
\hline \multicolumn{1}{|c|}{ Listed/OTC Graphs } & \multicolumn{2}{|c|}{$\begin{array}{c}\text { No. of Disclosure Graphs } \\
\text { for Listed Company is } \\
\text { Type of }\end{array}$} & $\begin{array}{l}\text { No. of Disclosure Graphs } \\
\text { for OTC Company is 75 }\end{array}$ & $\begin{array}{c}\text { No. of Disclosure Graphs } \\
\text { for Listed } \\
\text { Company is 366 }\end{array}$ \\
\cline { 2 - 7 } Inappropriate Graphs & No. & Ratio (\%) & No. & Ratio (\%) & No. & Ratio (\%) \\
\hline Masking & 48 & 16.49 & 4 & 5.33 & 52 & 14.21 \\
\hline Not Starting at the Origin & 16 & 5.50 & 4 & 5.33 & 20 & 5.46 \\
\hline $\begin{array}{l}\text { No Axis of Scale or Unequal Interval of } \\
\text { Scale }\end{array}$ & 15 & 5.15 & 1 & 1.33 & 16 & 4.37 \\
\hline Omission of Yearly Order & 4 & 1.37 & 1 & 1.33 & 5 & 1.37 \\
\hline Graph Drawing Error & 0 & 0 & 1 & 1.33 & 1 & 0.27 \\
\hline Total & 83 & 28.52 & 11 & 14.67 & 94 & 25.68 \\
\hline
\end{tabular}

Beattie and Jones (2000) discuss whether or not the choice of using graphs is related to good or bad performance of companies, especially with regard to profit and EPS. When profits or EPS are increased, a company may include graphs in its annual report. Tweedie and Whittington (1990) believe that company managers have motive and reason to use the bestmethod of displaying a company's performance. In addition, much research has discovered that companies in several countries have distorted measurements on their financial information graphs (Steinbart, 1989; Beattie and Jones, 1992, 1996; Mather et al., 1996; Courtis, 1997; Frownfelter and Fulkerson, 2001). Hence, several particular design and framework characteristics of graphs, such as choice of graph, use of background, and order of time sequences, enable companies to use the best style to display their achievements and performance (Beattie and Jones, 1992; CICA, 1993).

Meyer (1997) mentions that graphs are commonly used to formulate support decisions and convince readers in differing ways. Significantly, the graph designers may purposely not take due care, and may violate research or professionally recommended graph design parameters, because they have designed a graph to deliberately direct readers' attention to specific points. Tractinsky and Meyer (1999) indicated that when graph designers or managers are unsatisfied with either the financial information or performance, they tend to violate fundamental principles of graph design. Beattie and Jones (2000) found that companies mainly use graphs in their annual reports to manipulate and produce a better impression to their readers. Thus, deviations may exist on their reporting. Beattie and Jones (2002) further indicated that many graph users do not pay particular attention to graphic distortion until they exceed 20\%. This evidence supports prior research discoveries that readers may change their judgments of the performance of a company when the levels graphic distortions exceed $10 \%$.

Arunachalam and Steinbart's (2002) research showed that many companies around the world provide graphic information in their annual reports, but these graphs did not conform to normal graph format standards. In addition, they found that the design of a graph indeed influences most people's judgments and decisions behavior. Therefore, information providers are likely to use different information display formats to influence readers' decisions or policies. Contrarily, if graphs are accurately shown, people may prefer graphic designs that enhance a positive impression of the information. Hence, inappropriate graphic designs actually mislead people when making decisions, and cause them to make different decisions when they have seen an appropriate graphic design. This hypothesis is stated in $\mathrm{H} 2-1$ and $\mathrm{H} 2-2$.

H2-1: Using numerical tabulation of financial information has a different effect on the judgment of investors than using distorted graphs of financial information.

H2-2: Using non-distorted graphs of financial information has a different effect on the judgment of investors than using distorted graphs of financial information. 


\section{RESEARCH METHODOLOGY}

\section{Experimentation Design}

This research used experiment design application methods. Through the design of experiment methods, the researchers could manage independent variables and random sampling, handle the research boundaries, produce more detailed information, and effectively look into the real situation and environment. In addition, this led to more accurate and clearly defined management of variables, and showed an objective balance of the variables (Chen, 2004).

This research compared financial information disclosures among different disclosure types including numerical tables, non-distorted graphs and distorted graphs, with a total of three experiments to test our hypotheses. Each experiment was conducted individually and no experiment of the participants was repeated. Each scenario had 70 expected samples, a total of 210 (please refer to graph 3-1).

Table 3-1 Situation of Experimental Design among Scenarios

\begin{tabular}{|c|c|c|c|}
\hline $\begin{array}{c}\text { Information } \\
\text { Disclosure }\end{array}$ & $\begin{array}{c}\text { Information of Numerical } \\
\text { Table }\end{array}$ & $\begin{array}{c}\text { Non- Distorted Graphs } \\
\text { Information }\end{array}$ & $\begin{array}{c}\text { Distorted Graphs } \\
\text { Information }\end{array}$ \\
\hline Information Disclosure experiments & Experiment 1 & Experiment 2 & Experiment 3 \\
\hline
\end{tabular}

\section{Participants}

This research mainly investigated the possible effects between information display on the judgments of investors, and their interaction in three experiments. Stephan (2002) found that investors are able to influence the behavior of companies on their ability to buy company shares. Additionally, investors often must possess the ability to read financial reports and analyze financial situations so as to understand company development and performance. Hence, our participants were students with a background in business from business administration and accounting departments who had to have studied accounting and financial analysis classes for at least a year. In addition, all participants in this research must have investing experience in the stock market.

\section{Design Methods}

This research discusses the different influences over the judgments of investors on various patterns of display of financial information and the quality of financial information. Therefore, this research supposes that most participants who took part in the experiment are actual investors with fundamental financial and accounting knowledge. Murphy and Zimmerman (1993) believe that managers have the freedom to measure, disclose and express financial information that would trade off any signal of poor company performance. Therefore, when companies perform poorly, managers or companies may handle information and manipulate display methods so as to give signals of better performance. Contrarily, when a company performs well, the company may give a positive impression to their investor. Hence, we will design a virtual hi-tech manufacturing company (named Chao Lian Company) as a case study, and then present its financial situation and operations performance to the participants for analysis. 


\section{Independent Variables}

\section{Financial Information Display Methods}

(1). Numerical information: indicates displaying financial information numerically.

(2). Graphic non-distorted information: indicates displays which conform to Tufte $(1983)^{1}$ and Arunachalam and Steinbart's $(2002)^{2}$ standards of graphic design.

(3). Graphic distorted information: indicates displays which do not conform to Tufte (1983) and Arunachalam and Steinbart's (2002) standards of graphic design.

\section{Dependent Variables}

In this research, the variables of investors' judgments refer to prior research (Hopwood et al., 1994; Hodge, 2001; Chen, 2004) and the principle summarized as follows:

\section{Financial Performance Evaluation}

The perception of the company's financial performance in this experiment is subject to the cognizance of the investors. The variables of this item have been separated into three:

(1). evaluation of company's specific financial dimension.

(2). numerical grading of entire financial performance.

(3). six-scale grading evaluation of entire financial performance of the company.

\section{Stock Evaluation}

This indicates that participants gave a stock price value that they would be willing to purchase in accordance with the financial information provided in the experiment.

\section{Evaluation of Company's Financial Crises}

This refers to the investors' awareness of the company's bankruptcy and liquidation in compliance with the financial information provided in the experiment.

\section{Sample Selections}

Our research issued 210 questionnaires and each experiment scenario was split into 70 . The total number of questionnaires returned was 199, excluding seven null and void questionnaires. The success rate of returned questionnaires was $91 \%$. In addition, after eliminating the most extreme samples, the actual effective number of samples was 180 .

\footnotetext{
${ }^{1}$ These 6 items for the principles of graphic design which Tufte (1983) proposed are: the depiction of drawing/chart shall be proportioned to the variation of information; shapes of drawing/chart shall be marked clearly; the number of space using shall be limited; the change of drawing/chart design shall be responded to the the variation of information; the standard currency weighting is better than nominal currency weighting; and correctly display the content of tendency information.

2 Arunachalam and Steinbart's (2002) 4 items for the improper methods of graphic design are: distored weighting (not using 0 as the origin); cover up; reversed yearly sequence; and omittion of negative values.
} 


\section{EXPERIMENT RESULTS AND ANALYSIS}

\section{Descriptive Statistics}

Of the participants who took part in this research, the split between males and females was $50 \%$; $96.7 \%$ were aged between 20 and 29. The majority of participants held Master's degrees (50.6\%) as the highest level of academic qualification, and a large number held Bachelor degrees (49.5\%). Thus, the participants in the experiments were well-educated. (Please refer to table 4-1 for more information.)

Table 4-1 Personal Information Analysis of Participants

\begin{tabular}{|c|c|c|c|c|c|}
\hline Sex & No. of Person & Percentage & Age & No. of Person & Percentage \\
\hline \multirow{2}{*}{ Male } & \multirow{2}{*}{90} & \multirow{2}{*}{50.0} & $20-29$ & 174 & 96.7 \\
\hline & & & $30-39$ & 5 & 2.2 \\
\hline \multirow{2}{*}{ Female } & \multirow{2}{*}{90} & \multirow{2}{*}{50.0} & $40-49$ & 0 & 0 \\
\hline & & & Over 50 & 1 & 0.4 \\
\hline Total & 180 & 100.0 & Total & 180 & 100.0 \\
\hline $\begin{array}{l}\text { Education } \\
\text { Background }\end{array}$ & No. of Person & Percentage & $\begin{array}{c}\text { Experience of } \\
\text { Investment }\end{array}$ & No. of Person & Percentage \\
\hline Bachelor degrees & 89 & 49.5 & $1-2$ years & 161 & 89.4 \\
\hline Master Degree & 91 & 50.6 & 2-3 years & 9 & 5.0 \\
\hline Ph.D. & 0 & 0 & 3-4 years & 4 & 2.2 \\
\hline \multirow{2}{*}{ Others } & \multirow{2}{*}{0} & \multirow{2}{*}{0} & $4-5$ years & 5 & 2.8 \\
\hline & & & Over 5 years & 1 & 0.6 \\
\hline Total & 180 & 100.0 & Total & 180 & 100.0 \\
\hline
\end{tabular}

In table 4-2, we investigated the reference sources and observe that the participants were formulating investment decisions from a variety of media; much of their information $(65.6 \%)$ came from newspapers and the next biggest source of information was magazines and websites at $56.1 \%$ each. In other words, over half of the participants received their information from newspapers (65.6\%), magazines (56.1\%) and websites $(56.1 \%)$.

Table 4-2 Reference Source for Participants (multiple choice allowable)

\begin{tabular}{|l|c|c|c|c|c|}
\hline Reference Source & No. of Person & Percentage & Reference Source & No. of Person & Percentage \\
\hline Magazine & 101 & 56.1 & Company Publication & 26 & 14.4 \\
\hline Periodical & 55 & 30.6 & Websites & 101 & 56.1 \\
\hline Newspaper & 118 & 65.6 & Others & 9 & 5.0 \\
\hline
\end{tabular}

\section{Manipulation Test}

In order to understand whether or not the participants clearly understood the financial situation of the virtual company and to test whether or not the experiment was successful, we implemented an experiment manipulation test.

First, we introduced the fundamental financial situation of a virtual company to the participants in our experiments, and then asked them to fill out fives items after reading the virtual scenarios. These five items were separated, and participants were asked to rate each statement's verisimilitude: (1) the financial structure in 2003 of 
the Chao Lian Company was higher than in 2002. (2) The liquidity of the Chao Lian Company was better in 2003 than in 2002. (3) The operating capability of the Chao Lian Company was higher in 2003 than the previous year. (4) The cash flow of the Chao Lian Company was higher in 2003 than the year before. (5) The profitability of the Chao Lian Company was better in 2003 than in 2002. (1 point was equal to "strongly disagree", and 6 points to "strongly agree"). The results of these questionnaires were anticipated to lean towards 'agree'. That is, that the performance of the Chao Lian Company was greater in 2003 than in 2002. Table 4-3 shows that the mean of five items in the manipulation test was over 4, meaning that most participants agreed that the performance of the Chao Lian Company was better in 2003 than in 2002.

In addition, we implemented a ' $t$ ' test to test these five items to reconfirm whether participants really understood the financial situation of the virtual company. (3 points meant' strongly agree', meaning the performance of the Chao Lian Company was better in 2003 than in 2002, 2 meant 'agree', 1 meant 'slightly agree'; -1 meant 'slightly disagree', -2 meant 'disagree', and -3 meant 'strongly disagree'. Table 4-4 shows that the mean is close to 2 , and significant, which mean all participants understood the financial situation of the virtual company. It is a testament that the manipulation in our experiments was successful.

Table 4-3 The Mean of Five Items

\begin{tabular}{|l|c|c|c|}
\hline Test of Financial Information & Minimum & Maximum & Average \\
\hline Financial Structure & 4 & 6 & 5.04 \\
\hline Liquidity & 2 & 6 & 4.99 \\
\hline Operating Capability & 2 & 6 & 4.99 \\
\hline Cash Flow & 2 & 6 & 4.90 \\
\hline Profitability & 2 & 6 & 4.93 \\
\hline
\end{tabular}

Table 4-4 t Test

\begin{tabular}{|l|c|c|c|c|c|c|}
\hline & Degree of & \multirow{2}{*}{ Freedom } & t Value & p-value & Average & \multicolumn{2}{c|}{ 95\% Confidence Interval } \\
\cline { 5 - 7 } & & & & Difference & Lower Bound & Upper Bound \\
\hline Financial Structure & 179 & 47.517 & $0.000 * * *$ & 2.04 & 1.96 & 2.13 \\
\hline Liquidity & 179 & 35.517 & $0.000 * * *$ & 1.98 & 1.87 & 2.09 \\
\hline Operating Capability & 179 & 40.957 & $0.000 * * *$ & 1.99 & 1.89 & 2.08 \\
\hline Cash Flow & 179 & 26.930 & $0.000 * * *$ & 1.87 & 1.73 & 2.00 \\
\hline Profitability & 179 & 32.121 & $0.000 * * *$ & 1.91 & 1.79 & 2.02 \\
\hline
\end{tabular}

\section{Experiment Results}

From the results of the test, it was discovered that there were significantly different among participants tested in each scenario in terms of evaluation of grades of specific financial dimensions, numerical grading of entire financial performance, and six-scale grading of overall financial performance (please refer to table 4-5). Thus, we used Fisher's least significant different test (LSD) and discovered the discrepancies of items in dependent variables. As for the aspect of evaluation of specific financial dimensions, there were discrepancy between participants who received a numerical table and those who received graphic information. This demonstrates that the format of the expression of information is certainly linked to impression management. Identically, there were also discrepancies between numerical evaluations of entire financial expression and scale evaluations (please refer to table 4-6 for more detail). 
In hypothesis 1, we anticipated that the display of financial information in numerical tables or non-distorted graphs would have differing effects on the judgments of investors, with the use of graphs to display financial information being superior to numerical tables. Our results are demonstrated in Table 4-7, and indicate that there were discrepancies in specific financial dimension evaluation, entire financial numerical grades, and scale grades between the participants who received numerical tables (experiment 1) and non-distorted graphic information (experiment 2).

Table 4-5 F Test

\begin{tabular}{|c|c|c|c|c|}
\hline \multicolumn{5}{|l|}{ Test of Effective Items among Participants } \\
\hline Dependent Variable & $\begin{array}{l}\text { Degree of } \\
\text { Freedom }\end{array}$ & \begin{tabular}{|c|} 
Average Sum of \\
Square
\end{tabular} & F Test & Significance \\
\hline Evaluation of Specific Financial dimension & 5 & \begin{tabular}{|l|}
1.302 \\
\end{tabular} & 4.827 & $0.000 * * *$ \\
\hline Numerical Grading of Entire Financial Performance & 5 & 114.156 & 2.122 & $0.065^{*}$ \\
\hline Six-Scale Grading of Overall Financial Performance & 5 & 0.517 & 2.249 & $0.052 *$ \\
\hline Evaluation of Stock Price & 5 & 232.293 & 0.534 & 0.750 \\
\hline Evaluation of Financial Crisis & 5 & 379.379 & 1.543 & 0.179 \\
\hline
\end{tabular}

Table 4-6 Multiple Comparison

\begin{tabular}{|c|c|c|c|c|c|}
\hline \multicolumn{6}{|c|}{ Multiple Comparison (LSD) } \\
\hline Dependent Variable & $\begin{array}{l}\text { Manipulative } \\
\text { Situation } \\
\text { (I) } \\
\end{array}$ & $\begin{array}{c}\text { Manipulative } \\
\text { Situation } \\
(\mathbf{J}) \\
\end{array}$ & $\begin{array}{c}\text { Difference in } \\
\text { Average } \\
\text { (I-J) }\end{array}$ & Standard Error & Significance \\
\hline \multirow{4}{*}{$\begin{array}{l}\text { Evaluation of Specific } \\
\text { Financial Dimension }\end{array}$} & 1 & 2 & -0.323 & 0.095 & $0.001 * * *$ \\
\hline & & 3 & -0.403 & 0.095 & $0.000 * * *$ \\
\hline & 2 & 1 & 0.323 & 0.095 & $0.001 * * *$ \\
\hline & 3 & 1 & 0.403 & 0.095 & $0.000 * * *$ \\
\hline \multirow{2}{*}{$\begin{array}{l}\text { Numerical Grading of } \\
\text { Entire Financial } \\
\text { Performance } \\
\end{array}$} & 1 & 2 & -3.500 & 1.342 & $0.010 * * *$ \\
\hline & 2 & 1 & 3.500 & 1.342 & $0.010 * * *$ \\
\hline \multirow{4}{*}{$\begin{array}{l}\text { Six-Scale Grading of } \\
\text { Overall Financial } \\
\text { Performance }\end{array}$} & 1 & 2 & -0.167 & 0.088 & $0.059 *$ \\
\hline & & 3 & -0.233 & 0.088 & $0.008 * * *$ \\
\hline & 2 & 1 & 0.167 & 0.088 & $0.059 *$ \\
\hline & 3 & 1 & 0.233 & 0.088 & $0.008 * * *$ \\
\hline \multirow{2}{*}{$\begin{array}{l}\text { Evaluation of Financial } \\
\text { Crisis }\end{array}$} & 1 & 3 & 6.767 & 2.853 & $0.019 * *$ \\
\hline & 3 & 1 & -6.767 & 2.853 & $0.019 * *$ \\
\hline
\end{tabular}

This result supports part of Hypothesis 1. In addition, we found that participants given numeric tabulations of financial information in experiment 1 made more conservative investment decisions than those given non-distorted graphs of financial information. This is in accordance with the predication of the hypothesis and consistent with prior research (Tufte, 1983; Anderson, 1983; Jarett, 1993).These results also indicate that using graphs to express financial information certainly creates a different impression. 
Hypothesis 2-1 discusses the effects on investors' judgments by numerical tables or by distorted graphs of financial information. This research anticipated that there would be discrepancies between these two types of display financial information. Table 4-8 shows that there were discrepancies in participants' judgments when they receive numerical tables(experiments 1) compared with distorted financial graphics (experiments 3 ) with regards to specific financial dimension evaluations, entire financial scales displayed, and financial crisis evaluation. In the results, we found that participants who used distorted graphic information had a higher evaluation of the financial performance of company than those participants who viewed numerical tables. This is in accordance with the predicated results and shows the existence of impression management.

Hypothesis 2-2 discusses the issue of the influence of non-distorted and distorted financial graphic disclosures on the judgments of investors. We predict that there will be a discrepancy between the decisions of investors when regarding non-distorted and distorted graphs of financial information. Table 4-9 shows that this was not so (experiments 2 and 3), and so the results do not support Hypothesis 2-2. We believe that the lack of discrepancy on investors' decisions between distorted and non-distorted financial graphic information is caused by a failure on the part of the participants to clearly distinguish which graphs were distorted and which ones were not. Hence, there was also no significant discrepancy on participants' impression management of graphs. In other words, it is likely that the participants were not able to judge the actual performance of the virtual company in our experiment.

\section{Table 4-7 MANOVA Test Table of Hypothesis 1}

H1 : Using numerical tabulation of financial information has a different effect on the judgment of investors than using non-distorted graphs of financial information.

\begin{tabular}{|c|c|c|c|}
\hline (n) & Dependent Variable & F test Value & Significance \\
\hline \multirow{5}{*}{ H1 } & Evaluation of Specific Financial Dimension & 11.854 & $0.001 * * *$ \\
\hline & $\begin{array}{l}\text { Numerical Grading of Entire Financial } \\
\text { Performance }\end{array}$ & 8.072 & $0.005 * * *$ \\
\hline & $\begin{array}{l}\text { Six-Scale Grading of Overall Financial } \\
\text { Performance }\end{array}$ & 4.766 & $0.031 * *$ \\
\hline & Evaluation of Stock Price & 1.734 & 0.190 \\
\hline & Evaluation of Financial Crisis & 2.388 & 0.125 \\
\hline
\end{tabular}

The significance levels are as follows:*significance at $10 \%$ level ;** significance at $5 \%$ level; *** significance at $1 \%$ level

Table 4-8 MANOVA Test Table of Hypothesis 2-1

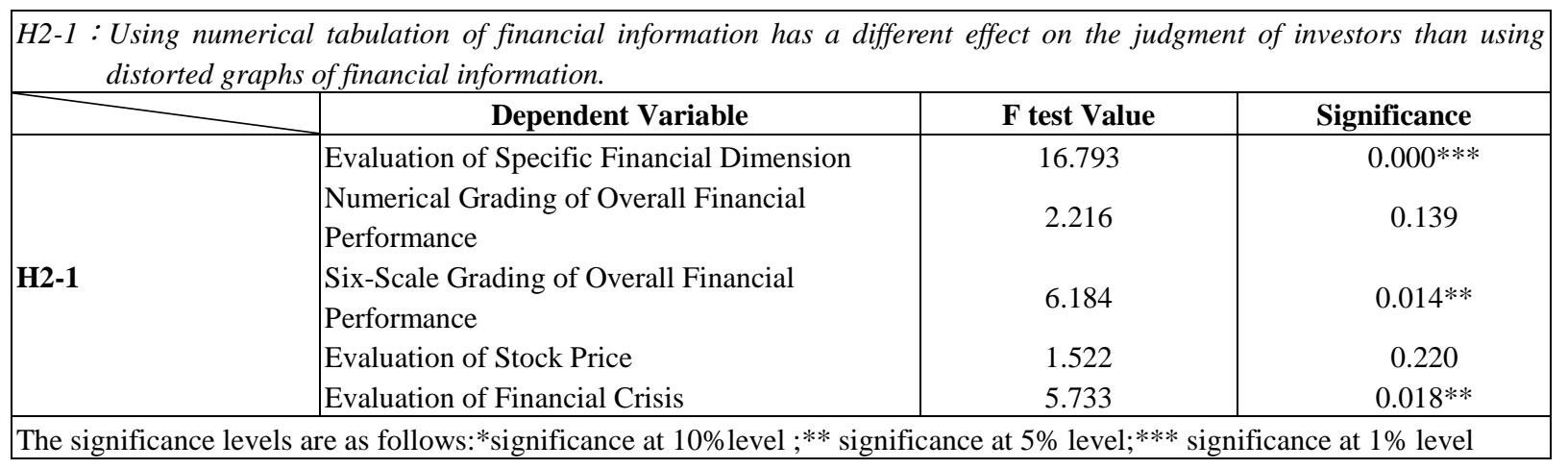


Table 4-9 MANOVA Test Table of Hypothesis 2-2

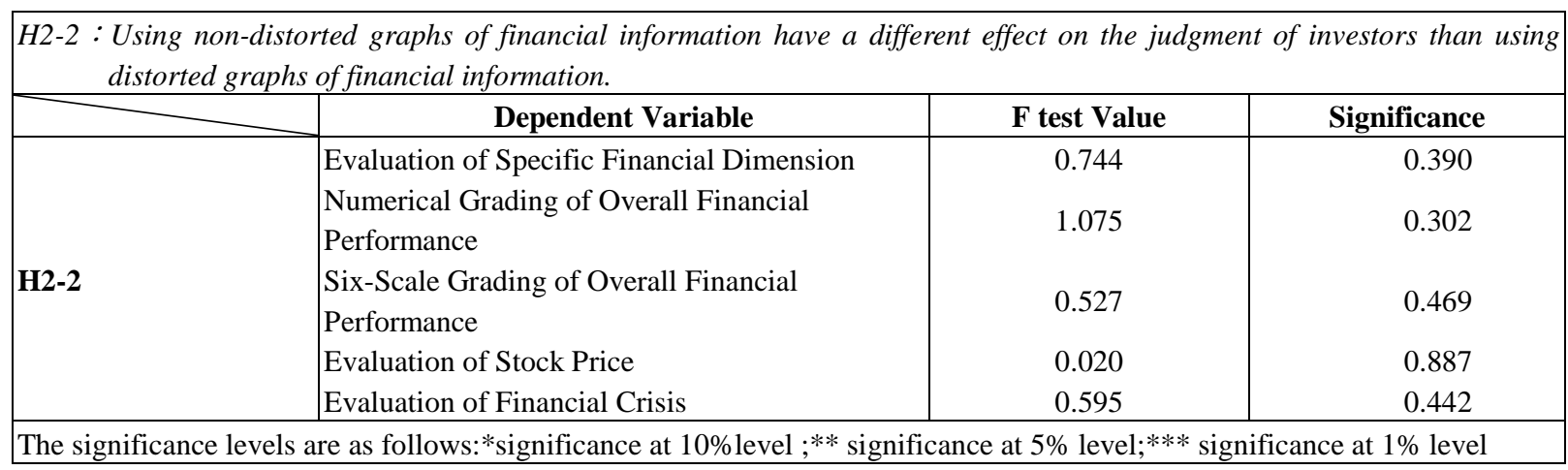

\section{CONCLUSION AND RECOMMENDATIONS}

In many countries, graphs have been widely used to display financial information for a long time. This is a special characteristic of rapid information communication and collection by graphs; thus, the use of graphs can be used to manipulate impressions (known as impression management) (Carswell, 1991; Courtis, 1997). This research discovered this phenomenon is a problem. The participants who received graphic financial information from our experiment demonstrated better decision-making and judgment skills over a company's financial performance than those who received information without graphs. However, the participants were not able to judge the difference between non-distorted and distorted graphs of financial information. The reason is probably that our research used information from companies with good financial performance. If we had used companies with bad financial performance, the results might have been different. This is a limitation of our study.

According to an investigation of the websites of listed companies in Taiwan, we found that $25.68 \%$ of them already use graphs to distort information. And, in determining whether graphic distortions affect investors' decisions, we found that the decisions made by participants in scenarios with graphic distortions were certainly influenced more than those who never saw the graphs. Moreover, participants could not clearly identify whether or not the graphs had been distorted when the graph designers purposefully manipulated the graphs. Consequently, the Accounting Standards Board needs to establish criteria regulating graphs, and management authorities and bodies should restrain and punish those companies that use graphs to distort information.

Finally, in order to avoid affecting the judgments and decisions of investors, many companies in Taiwan do not use financial graphics in their annual reports, with the consequence that the financial information is not lively and animated. Therefore, we do recommend that management authorities and bodies provide a way for information to be disclosed within annual reports via the use of graphs, but only in the context of establishing regulations for graphic disclosure.

\section{AUTHOR INFORMATION}

Shaio Yan Huang is an Associate Professor of Department of Accounting and Information Technology at National Chung Cheng University and teaches Accounting Information System, Advanced Auditing, and Financial Accounting. He is a member of the International Affair and Education Board in Information Systems Audit and Control Association (ISACA), Taiwan Chapter. His researches include financial accounting, accounting information system, auditing.

Yu-Hsuan Chung is a Ph.D. program student of Department of Accounting at National Chengchi University. He completed his Master degree at Department of Accounting at Feng Chia University. His main research area focuses 
on accounting information system, financial accounting, and managerial accounting.

Wen-Wei Cheng is an auditor of Deloitte \& Touche CPA firm in Taiwan. He obtains his Master degree at Department of Accounting at Providence University. His research area is accounting information system.

\section{REFERENCES}

1. Anderson, A. 1983. Graphing financial information : How accountants can use graphs to communicate. New York, National Association of Accountants.

2. $\quad$ Anderson, R. H., and M. J. Epstein. 1996. The usefulness of corporate annual reports to shareholders in Australia, New Zealand, and the United States : An international comparison. JAI Press.

3. Arunachalam, V., B. K. W. Pei, and P. J. Steinbart. 2002. Impression management with graphs : Effects on choices. Journal of Information System, 16(2), 183-202.

4. ASB, 2000. Year-end financial reports : Improving communication. Discussion Paper, Accounting Standards Board, February.

5. Bartlett, S. A., and R. A. Chandler. 1997. The corporate report and the private shareholder : Lee and Tweedie twenty years on. British Accounting Review, 29(3),245-264

6. Beattie, V. A., and M. J. Jones. 1992a. The communication of information using graphs in corporate annual reports. Certified Research Report 31, Chartered Association of Certified Accountants, Certified Accountants Educational Trust.

7. Beattie, V. A., and M. J. Jones. 1992b. The use and abuse of graphs in annual reports : A theoretical framework and empirical study. Accounting and Business Research, 22(88),291-303.

8. Beattie, V. A., and M. J. Jones. 1996. Financial graphs in corporate annual reports : A review of practice in six countries. Research Report, Institute of Chartered Accountants in England and Wales.

9. Beattie, V. A., and M. J. Jones. 1997. A comparative study of the use of financial graphs in the corporate annual reports of major U.S and U.K companies. Journal of International Financial Management and Accounting,8(1),33-68.

10. Beattie, V. A., and M. J. Jones. 1999. Australian financial graphs : An empirical study. ABACUS,35(1), 46-76.

11. Beattie, V. A., and M. J. Jones. 2000. Impression management : The case of inter-country financial graphs. Journal of International Accounting, Auditing and Taxation 9, 159-183.

12. Beattie, V. A., and M. J. Jones. 2002. The impact of graph slope on rate of change judgments in corporate reports. ABACUS, 38(2),177-199.

13. Beattie, V. and M.J. Jones (2004) Measurement distortion of graphs in corporate reports: an experimental study. Accounting, Auditing and Accountability Journal, 15(4), 546-564.

14. Blocher, E., R. P. Moffie, and R. W. Zmud. 1986. Report format and task complexity : Interaction in risk judgments. Accounting, Organizations and Society,11(6),457-470.

15. Canadian Institute of Chartered Accountants (CICA). 1993. Using ratios and graphics in financial reporting : Research report. Toronto : Canadian Institute of Chartered Accountants.

16. Carswell, C. M. 1991. Boutique data graphics : Perspectives on using depth to embellish data displays. In Proceedings of the Human Factors Society $35^{\text {th }}$ Annual Meeting, 1532-1536. Santa Monica, CA : Human Factors and Ergonomics Society.

17. Chen Peu-Chin, 2004, Influence of Environmental Information Disclosure on Enterprises Financial and Non-financial Performance, unpublished thesis of Master degree, Providence University

18. Courtis, J. K. 1997. Corporate annual report graphical communication in Hong Kong : Effective or misleading ? . The Journal of Business Communication, 34(3), 269-288.

19. Cunningham, E. 1990. Up there with the best and deservedly so. Accountancy Age 10.

20. DeSanctis, G., and S. L. Jarvenpaa. 1989. Graphical presentation of accounting data for financial forecasting : An experimental investigation. Accounting, Organization and Society 14 (5-6), 509-525.

21. Epstein, M. J., and M. L. Pava. 1993. The shareholder's use of corporate annual reports. JAI Press. 
22. Frownfelter, C. A., and C. L. Fulkerson. 1998. Linking the incidence and quality of graphics in annual reports to corporate performance : An international comparison. Advances in Accounting Information Systems 6, 129-151.

23. Gillian, D. J., C. D. Wickens, J. G. Hollands, and C. M. Carswell. 1998. Guidelines for presenting quantitative data in HFES publications. Human Factors 40, 28-41.

24. Hodge, F. D. 2001. Hyperlinking unaudited information to audited financial statements : Effects on investor judgments. The Accounting Review, 76(4), 675-691.

25. Holmes, G. 1984. How to present your message graphically. Accountancy, 64-71.

26. Hopwood, W., J. Mckeown, and J. Mutchler. 1994. A reexamination of auditor versus model accuracy wityin the context of the going concern opinion decision. Contemporary Accounting Research, 10(2), 403-432.

27. Horton, W. 1993. The almost university language : Graphics for international documents. Technical Communication 40, 682-693.

28. Hussey, R. 1990. Accuracy with a dash of panache. AA Magazine, 18-25.

29. Jarett, I. 1993. Computer graphics and reporting financial data. New York : John Wiley.

30. Johnson, J., R. Rice, and R. Roemmich. 1980. Pictures that lie : The abuse of graphs in annual reports. Management Accounting 62, 50-56.

31. Leivian, G. M. 1980. How to communicate financial data more efficiently. Management Accounting (USA), $31-34$.

32. Mather, P., A. Ramsay and A. Serry. 1996. The use and representational faithfulness of graphs in annual reports : Australian evidence. Australian Accounting Review, 6(2), 56-63.

33. Mather, P., A. Ramsay and A. Steen. 2000. The use and representational faithfulness of graphs in Australian IPO prospectuses. Accounting, Auditing and Accountability Journal ,13(1), 65-83.

34. Meyer, J. 1997. A new look at an old study on information display: Washburne (1927) reconsidered. Human Factors 39, 333-340.

35. Murphy, K. J., and J. L. Zimmerman. 1993. Financial performance surrounding CEO turnover. Journal of Accounting and Economics, 16(1), 273-315.

36. Paivio, A. 1974. Spacing of repetitions in the incidental and intentional free recall of pictures and words. Journal of Verbal Learning and Verbal Behavior 13, 497-511.

37. Stephan, M. 2002. Environmental information disclosure programs : they work, but why? Social Science Quarterly, 83(1), 190-205.

38. Steinbart, P. J. 1989. The auditor's responsibility for the accuracy of graphs in annual reports : Some evidence of the need for additional guidance. Accounting Horizons, 3(3), 60-70.

39. Tractinsky, N., and J. Meyer. 1999. Chartjunk or goldgraph ? Effects on presentation objectives and content desirability on information presentation. MIS Quarterly 23, 397-420.

40. Tufte, E. R. 1983. The visual display of quantitative information. Cheshire, CT : Graphics Press.

41. Tweedie, D., and G. Whittington. 1990. Financial reporting : Current problems and their implications for systematic reform. Accounting and Business Research, winter, 87-102

42. Vessey, I. 1991. The paradigm of cognitive fit: An information processing analysis of the table versus graph controversy. Decision Sciences, 22(2), 219-240.. 